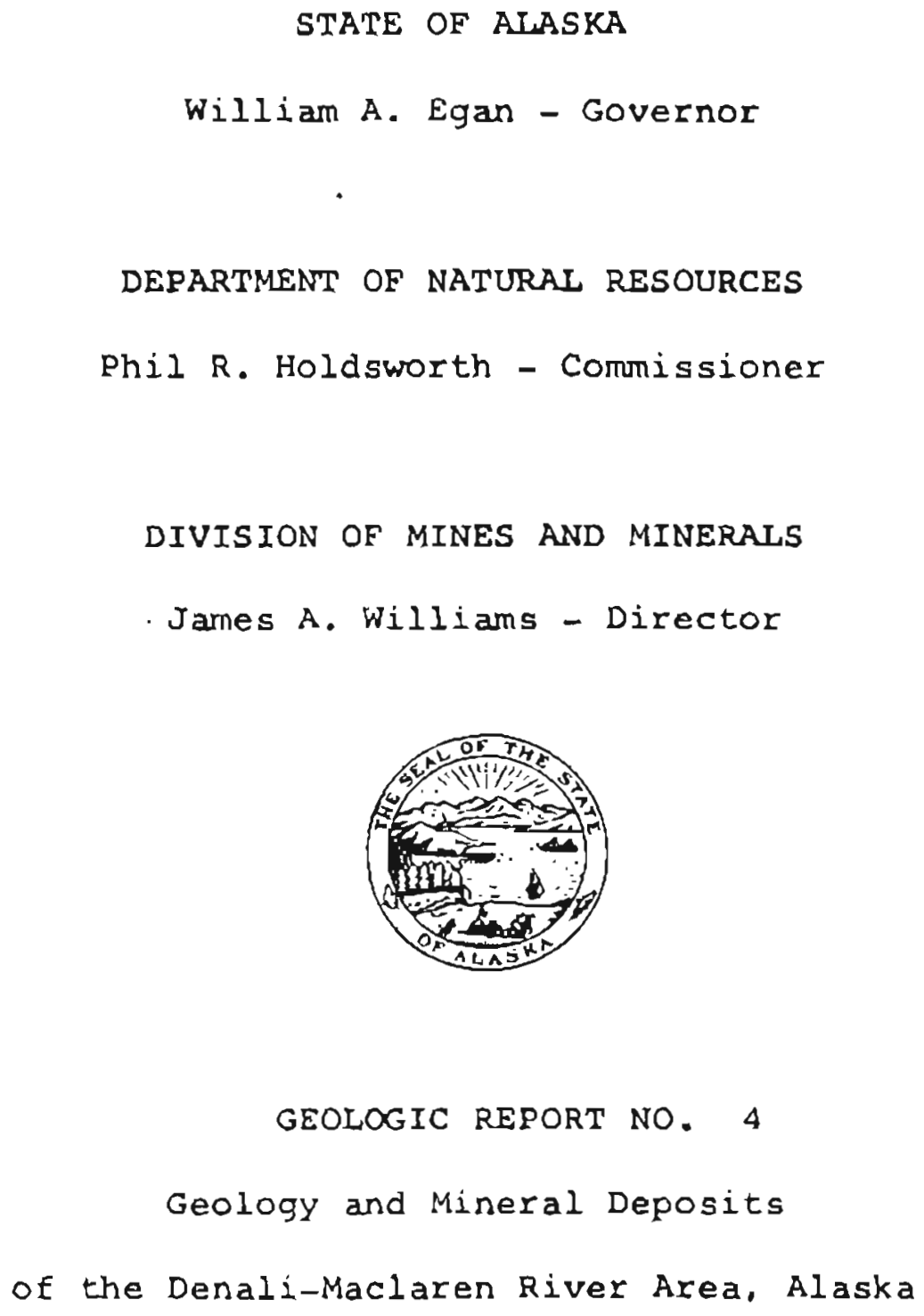




\section{GEOLOGY AND MINERAL DEPOSITS \\ OF THE DENALI-MACLAREN RIVER AREA, ALASKA}

By

M. A. Kaufman

\section{INTRODUCTION AND SUMMARY}

Placer gold and minor amounts of lode gold have been mined in the Valdez Creek district, and numerous occurrences of copper are known in the area between Butte creek and Maclaren Glacier (Saunders, 1961 ). Geological mapping at scales of 1 inch to 4 miles and 1 inch to 2 miles has been done by the U.S. Geological survey (Moffit, 1912; Ross, 1933) and several airborne reconnaissance trips have been made by Alaska Division of Mines and Minerals engineers, but except for the Kathleen-Margaret prospect, (Chapman and Saunders, 1954), no descriptions of the copper deposits are available.

The author and an assistant spent from June 12 to August 31 , 1963, in the area. The results of the program are: (1) a reconnaissance 1 inch to 1 mile geological map showing the relationship between the mineral occurrences and the regional geology, (2) descriptions of all known mineralized localities, and (3) a drainage geochemical study of the whole area. Several mineral occurrences that apparently have not been prospected were encountered during the mapping. Two of these, localities 8 and 12, merit further work. It should be emphasized that the mapping was of a reconnaissance nature, mainly concentrating along the drainages where outcrop was relatively abundant. There is considerable room for further geological work and prospecting, especially in the high areas which were either snow-covered at the time of mapping, or were inaccessible by foot. 


\section{GEOLOGY}

The dominant rock units in the map area can be grouped into two paraliel northeasterly trending belts. The southern part of the map area is underlain by a thick section of volcanic rocks with minor amounts of sedimentary material. The northern portion is underlain by a thick sedimentary section with minor amounts of volcanic rock. A large diorite stock lies immediately to the north of the map area and small stocks of acidic composition intrude both the sedimentary and volcanic belts.

Development of slates, phyllites, and schists is observed near the contact between the sediments and the large stock, and local zones of metamorphism occur adjacent to some of the small stocks.

There is little evidence by which to date the rock types in the mapped area. By comparison of the lithology with other areas, plus some fossil evidence, Moffit (1912، p. 29-35) concluded the volcanic belt to be Permian to lower Triassic, the limestone units near the contact between the belts to be lower to middle Triassic, and the thick sequence of argillite and quartzite in the northern belt to be late Triassic. It should be noted that limestones are found interbedded both with volcanics and with sediments rather than forming a distinct stratigraphic horizon. The intrusives have been dated only as postTriassic.

The rocks of the volcanic belt are predominantly Eine grained massive to amygdaloidal, gray to reddish gray, andesitic to basaltic lavas. In many localities these lavas have been partially metamorphosed to greenstone. Associated with the lavas are fine-grained dike rocks of intermediate to basic composition, light green to gray siliceous felsite tuffs, fragmental units with andesitic matrix, minor amounts of black argillite, and thin bands of gray limestone.

The sedimentary belt is composed dominantly of black finegrained banded argillite, with lesser amounts of fine-grained gray impure quartzite. Minor amounts of andesite and andesite fragmental rocks are interbedded with the sediments, and in one area light gray quartzose felsite occurs. Massive to finely-banded light gray limestone, in places fossiliferous, and gray argillaceous limestone occur along the contact between the sedimentary and volcanic belts. These limestone units, which are in places interbedded with argillites and in other places with volcanics, aggregate over one thousand feet thick in some areas. This great thickness may be due to the repetition of the section by folding and faulting, but the details are obscured by heavy overburden. Limy beds occur along the sedimentary-volcanic contact 
wherever it can be observed from the mountains south of Butte Creek to the Maclaren Glacier, and it is probable that some of the limestone units have considerable continuity along the strike.

An intrusive body about 15 miles in diameter, predominantly of dioritic composition, and locally with gneissic texture, has been described by Moffit (1912, p. 34-35) and Ross (1933, p. 446) immediately to the north of the map area. The contact is about 2 miles north of Valdez. Creek. Smaller stocks ranging in composition from granite to quartz diorite intrude the volcanics and sedimentary rocks in several areas. Basic intrusive rocks are rare in the sedimentary belt but do occur locally in the Butte creek area and in the West Fork of the Maclaren area where dunite was found at one locality.

Biotite schists crop along Valdez Creek from Denali to Roosevelt Lake, and higher grade metamorphism is reported to the north of this area in proximity to the diorite contact (Ross, 1933, p. 437). Local schistose zones occur adjacent to the intrusive along the north side of windy creek. Evidence of low grade metamoxphism occurs in many of the volcanic outcrops which display minox green coloring caused by the formation of chlorite and epidote, but schistose greenstone is not common. A small body of biotite-chlorité schist derived from volcanics occurs adjacent to the incrusive body on the east side of the West Fork of the Maclaren River, and zones of amphibolitized greenstone occur in numerous areas between the West Fork and the Maclaren River. It is possible that these amphibolitized zones represent volcanic rocks that are underlain at depth by intrusives.

Several differences in lithologic interpretation exist between this investigation and the previous geological work by Moffit (1912) and Ross (1933). Ross, on his map (1933, plate 34), shows the following 1ithologic units: TRs schist near Valdez Creak: TR tuffaceous and re. lated strata intercalated with limestonen and TRrs rusty schist with intercalated chloritic beds. This author considers the TRs unit of Ross to be metamorphosed rock derived from the argillite-quartzite series, the degree of metamorphism possibly being dependent upon proximity to adjacent or subjacent intrusives. Further, the tuffaceous rocks and related extrusives are considered to be individual units rather than a broad lithologic unit. Field evidence has shown relatively thin beds of tuff and volcanic breccia to occur both in the volcanic and sedimentary belts. The TRrs (xusty schist) unit in the coal creek area is interpreted to represent pyrite-bearing felsites interbedded with greenstone, and for this reason has not been mapped as a distinct unit. 


\section{STRUCTURE}

A general rocichasterly trend of contacts and bedding occurs throughout the area. Strucziral atitudes in the sedimentary jelc reveal complex folds with variable plunges but with a general northeasterly irend of axes. A preponderance of beoding strikes and fold axes ile between $N 50^{\circ} \mathrm{E}$ and $\mathrm{N} 80^{\circ} \mathrm{\Xi}$. Open folding is visiole in argillites and quartzites north of findy creek but it grades into iighter plunging folds which clearly show ul in the limestones along the south fork of Pass Creek and the Haclaren Glacier. The little available structural evidence in the volcaric belt also poincs to a general northeasterly strike, but siructural attitudes are nearly impossible to determine due to the massive nature of the rocks. The faule, shown by Ross (1933), northeast of Tenas lake nay not exist. The marked change in lithology in this area may well be explained by a gradation in metamorphism from slaty and phyllitic argiliite in the east to more schisiose rocks to the west.

No major structures were detected in the area, but minor faulting is prevalent throughour. Northeasterly and northwesterly trending faults occur in the mountains south of Butte creek, and northwesterly. striking faulis are visible south of Windy Creek. An extensive north-

- easterly scriking iron carbonate zone may represent a fault zone immediately to the east of the Greathouse Copper showing south of windy Creek. The area between the Wcst Fork and the Maclaren River shows fracturing and faulting both in rorth-south and east-west directions. A study of air photos would probably be helpful in outlining possible Eaults, but these were not available.

\section{MINERAL OCCURRENCES}

Known occurrences in the Denali-iaclaren area can be classified into four general types: placer gold closely associated with lode gold in quartz and carbonate veinlets cutting intrusive and sedimentary rocks, metal occurrences associated with volcanic rocks, metal occurrences associated with sedimentary-intrusive contact zones, and metal occurrences in intrusive rocks.

Most of the copper occurrences are the type associated with volcanic rocks, chiefly andesitic to basaltic greenstone. The frequency of these occurrences throughout the area points to an anomalous amount of copper in the volcanic rocks. These deposits occur as discrete quartz veins as at the Maclaren prospect, as shear or fracture zone mineralization associated with quartz, calcite, and epidote as at the Greathouse prospect, anc as pod-like segregations and amygdule fillings associated 
$\because$ in quizzz, calcite, and apiclote with no apparent structural control. line ixinary minerals of these occurrences are bornite, chalcopyrite, anci chalcocice associated with the above mentioned gangue minerals. iinor anounits of gold and silver occur with the copper at the Maclaren grospect and traces of silver occur with the copper at the Greathouse prospect. All the known occurrences will be described in the following section.

\section{DESCRIPTIONS OF MINERALIZED AREAS}

Location 1: Valdez Creek District. Over $\$ 500,000$ has been derived from placer gold production from the Valdez Creek district. Detailed descriptions of the regional geology and the mining operations can be obtained from the reports of moffit (1912) and Ross (1933). Lode gold production has been limited to a few excremely small high grade pockets in quartz and carbonace veins cutting quartz diorite at Timberline creek, and argilites and diorite about 3 miles to the east. The source of the Valdez cieek placer gold is probably veins of the type mencioned above. There is a strong possibility that more lode deposits exist in the area, but prospecting is hindered by heavy overburden.

Location 2: Halachite-stained float containing disseminated bornite and chalcocite associated with epidote is present in the drainage at 3250' elevation. Rocks in the area consist of gray to reddish gray volcanics of andesitic to basaltic composition striking $N 35-55^{\circ}$ E and dipping $55^{\circ} \mathrm{W}$. Because of snow cover the lode source was not found, but the float probably represents a small pod-like body or vein.

Location 3: C. R. Greathouse propexty. Malachite-stained bornite and chalcocite associated with quartz, epidote, and calcite occur along a narrow shear zone striking $N 55^{\circ} \mathrm{W}$, and dipping vertically. The wall rock consists of northeasterly striking black basaltic lava cut by a narrow, northwesterly trending dike of quartz diorite composition immediately to the northeast of the shear zone. The maximum width of the mineralized shear zone is 3 feet and the copper tenor is reported to xun as much as 11 per cent across this width in one chip sample. Although the structure can be traced for several thousand feet along strike, the three foot width of the mineralized section persists for less than 100 feet. Along the remainder of the shear zone mineralization is erratic, occasionally showing widths of a few inches. Several other northeasterly striking shear zones occur in the area but contain no visible copper. A narrow northeasterly striking iron-bearing carbonate zone occurs to the northeast of the Greathouse claims and may indicate a fault zone. Small fragments of limestone, some containing traces of 
Scrnite, occur in the talus, but none could be found in place above the mineralized zone. These probably represent thin limestone units interbedied with the volcanics. Several hundred feet north of the showing a thin northeasterly striking bed of limestone with a northwesterly dip was observed from the air.

Location 4: A small occurrence of copper has been reported in greenstone at this locality but was not observed during this investigation. The northeasterly striking linear zone of rusty stained carbonate mentioned previously which probably represents a fault, runs to the north of this area.

Location 5: A large area of rusty colored staining in this area is caused by irregular zones of iron-bearing carbonate cutting andesitic and basaltic lavas. It is probable that the linear carbollate zones represent alteration along faults. The rusty color is enhanced by the presence of reddith colored volcanic units. Several scatterea small occurrences of oxicized copper minerals associated with epidoce pods occur in the stained area.

Location 6: A smali occurrance of copper has been reporici in greenstone at this locality but was not observed during this investigation.

Location 7: Minor amounts of weakly mineralized copper jesring float occur in the drainage. Mineralization appears to be associated with epidote in lavas.

Location 8: (See special map of location 8) A copper shoviing in a fragmental unit consisting of limestone fragments in an andesitic matrix occurs at an elevation of 4,650 feet on a southeasterly flowing drainage which flows into the south fork of Pass Creek. The fragmental unit, which is cut by irregular dikes of gabbroic composition, is in contact with greenstone both above and below. Limestone units are interbedded with the greenstone. The fragmental formation appears to be a volcanic breccia rather than a structural zone of brecciation. The gossan consisis chiefly of limonite, malachite, azurite, and minor visible chalcopyrite. The stronger mineralization replaced limestone fragments while less intense mineralization occupies Eractures in the andesitic matrix. Two zones of mineralization occur along the northeasterly bank of the drainage. The moxe northwesierly (upstream) showing measures 33 feet across strike, and the downstreari showing measures 2 feet across strike. The two occurrences are separated by 200 feet of barren breccia and volcanics. The mineralized zones appear to strike between $\mathrm{N} 40^{\circ} \mathrm{E}$ and $\mathrm{N} 60^{\circ} \mathrm{E}$, and dip steeply. There is a possibility that they might represent one folded unit with 
ÉL $5500^{\circ}$

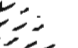

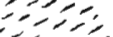

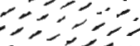

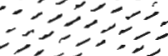

$\because$

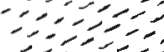

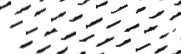

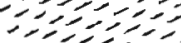

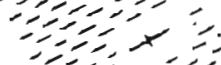

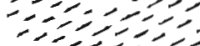

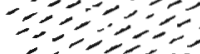

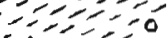

$0=\div 0$

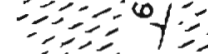

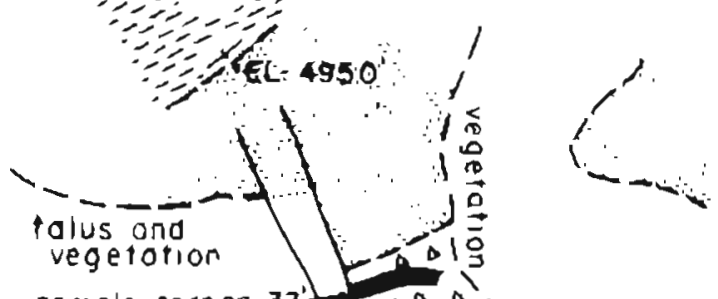

somple $\propto$ cross 33. $\Rightarrow 3^{\circ}$

Cu $2.9 \%$

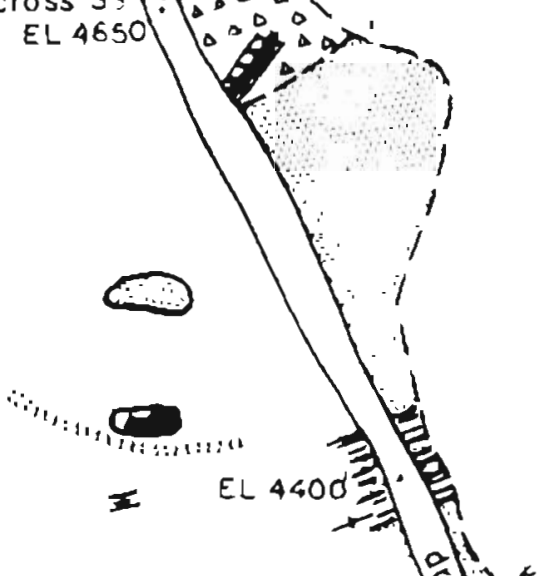

STATE OF ALASKA

DIVISION OF MINES AND MINERALS

\section{SOUTH FORK OF PASS CREEK \\ LOCATION 8 \\ COPPER SHOWING}

2 Gossan wimonite an l oxidized copper in outcrop

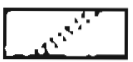

Gosson in floot

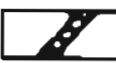

Gabbro dikes

A: Volconic trogmental flimestone frogments in an andesitic motrix)

$==$ Limestone w/ minar argillite

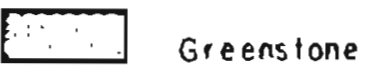

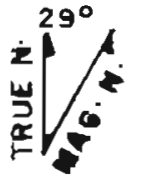

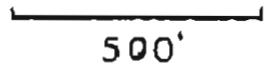


a nose to the northeast. Mineralized float, some showing spectacular oxidized copper, assaying up to 25 per cent copper can be traced for over 500 ieet along cine jide of a talus slope on the southwest side of the drainage. Some mineralized material occurs in place on the southwest side of the drainage, so it is probable that the float is close to its source.

In the exposure along the creek a chip sample across 33 feet width asizs 2.9 per cent $C u$. The geological environment of a mineralized breccia zone in interbedded volcanics and limestones with a sizable acidic intrusive body to the west lends encouragement to careful prospecting in the area.

Locitjon 9: Large areas of rusty colored limonite-hematite staining occur in easterly to northeasterly striking folded andesitic to basaltic greenstones with interbedded limestones. A small intrusive body of granodiorite composition cuts the volcanics south of the stained zones. The stainid areas that were examined axe caused by weathering of disseminaices pyrite in felsite bands, weathering of iron bearing carbonate ennes in andesite, and by forruginous cement in a brecriated roise. Further prospecting is warranted to investigate the composition of the more inaccessible stained zones.

Focation 10: Small amounts of copper bearing float occur throughout a $\because$ ck sicle at this locality. Malachite, azurite, chrysocolia, bornite, and chalcocite associated with quartz, calcite, and epiciote occur in pods and stringers cutting andesitic to basaltic lava. A traveire ais

Iucatich 13: sinor traces of chalcopyrite in isolated stringers occui ir the greenstone and in the intrusive in widely scattered areas. Tris oieces of float found in the drainage valley at an elevation of 4,000 fieet displayed banded magnetite-chalcopyrite, and banded inalachite-azurite. The source area of this occurrence is probabiy a considerzile distance upstream.

Iocation 12: An extensive rusty colored iron-stained area caused chiefly oy oxidation of iron-bearing carbonate and disseminated pyrite occurs in northeasterly striking folded argillites. Talus reveals a conciclerble amount of fine to medium-grained acidic intrusive rock wich must come from the center of the stained zone. Most of the intrusive contains an anomalous amount of disseminated pyrite. and some of the pieces reveal disseminated chalcopyrite and molybdenite. An assay of a grab sumple revealed 0.15 to 0.25 per cent Mo. Minor amounts of iolyhdenite-bearing quartz also occur in the talus. Because 
of the severe topography and lack of outcrop due to talus it was not possible to properly evaluate the extent of the mineralization in the intrusive. It is arobable that most of the intrusive found in the talus represents dikes, but it is possible that a small stock occurs somewhere in the stained zone.

Location 13: Splashes of malachite and azurite occur sporadically over a width of approximately 100 feet along the north wall of an east-west trending drainage at an elevation of 3400 feet. The oxidized copper represents primary bornite and chalcopyrite associated with quartz, epidote, and calcite localized along fractures in andesitic to basaltic greenstone. Some of the larger fractures strike approximately north-south and have vertical dips, but most of them are variable in direction and dip. A narrow dike of quartz hornblende diorite cuts the volcanics approximately 100 feet below the showing. None of the mineralized fractures exceed a few inches in width and they are widely separated with only minor dissemination of sulfides between them. A small amount of oxidized coppex is visible on the south wall of the drainage. The areas to the north and south are covered by vegetation.

Location 14: Abundant quartz and carbonate veinlets cut the argillites in this area. Most of them run parallel to the strike of the sediments but some are crosscutting. No ore minerals were detected in any of the veins examined, but there is a similarity between this type of veining and the type that is the probable source of the gold in the Valdez Creek district.

Locztion 15: whe southernmost two showings consist of talus containing small amounts of typical quartz-epidote material in greenstone with traces of chalcopyrite, bornite, chalcocite, and malachite. The sources are probably small mineralized pods or fractures in the greenstone. The occurrence in the drainage is similar to the others except that some of the copper occurs in amygdule fillings.

Location 16: Bornite ana oxidized coppex minerals, associated with small pods and stringers of quartz and epidote, occur in basaltic greenstone. Tho pods and siringers are widely spaced, sparsely mineralized, and have no apparant continuity.

Location 17: KM-ilaclaren Prospect. The Maclaren prospect (see special map of location 17) occurs in the thick northeasterly trending belt of massive intermediate to basic lavas and associated fine grained basic intrusive rocks that have been cut by widely spread porphyritic dikes of monzonite to diorite. The rocks are moderately fractured and faulted in many directions. Outcrop is sparse with good 


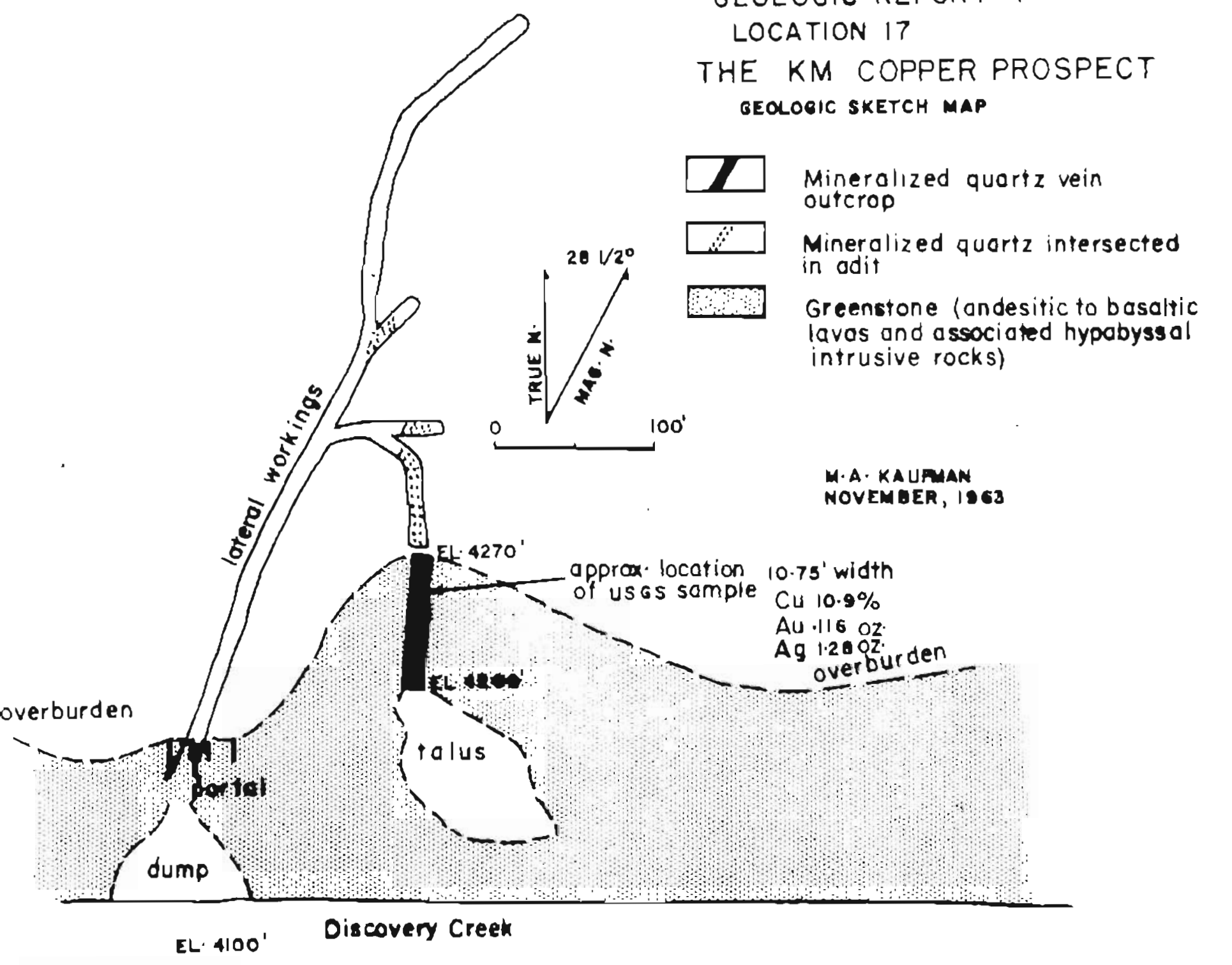

STATE OF ALASKA

DIVISION OF MINES AND MINERALS GEOLOGIC REPORT 4

LOCATION 17 GELOQIC SKETCH MAP

Mineralızed quariz vein

Mineralized quartz intersected odit

Greenstone (andesitic to basalic avas and associated hypabyss a

M.A. KA UPAAN

NOVEMOER, 1963

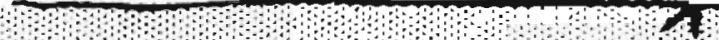


exposures only along the drainages. The discovery outcrop is on the north wall of an east-west trending dxainage (Discovery Creek) and almost all of the area to the north and south has a heavy overburdon cover. Several widely separated copper-bearing quartz veins, generally northeasterly or northwesterly striking and steeply dipping, occur in the area but most of them are only a few inches in width. A series of wider (up to 2 feet) but sparsely minexalized quartz veins, with approximate northerly strikes and steep dips, occur over a width of 50 feet in chloritized and epidotized greenstone immediately above the Maclaren portal. Approximately 150 feet east of the portal and 100 feet above it, a heavily mineralized chalcopyrite-bornite bearing quartz vein 10.5 feet wide, striking $N 3^{\circ} \mathrm{E}$ and dipping $80^{\circ} \mathrm{W}$, crops out for approximately 80 feet down dip. Sampling at one point across the vein by the U. S. Geological Survey and Alaska Division of Mines and Minerals disclosed $0.12 \mathrm{oz}$. Au, $1.2 \mathrm{oz}$. Ag, and 10.9 per cent Cu across a width of 10.75 feet (Chapman and Saunders, 1954, p. 5). This vein extends for an unknown aistance to the north but does not appear across Discovery Creek to the south.

A northeasterly trending adit has been driven immediately under the sparsely mineralized veins to the west of the heavily mineralized vein, and a short east trending crosscut approximately 200 feet from the portal intersects the latter vein. A program of percussion and diamond drilling was carried out from the workings to test the vein at depth but the results are not known by the author. In the workings the vein is consistent in width with the surface showing but the tenor does not appear to approach the surface values. The fact that the vein does not appear on the south side of the creek can possibly be explained by east-west faulting which might displace it. Only negligibie amounts of ore minerals or hydrothermal alteration are visible in the greenstone host rocks, and although numerous faults and fractures are observed. the area does not appear to have been structurally deformed to a greater degree than the rest of the volcanic belt extending from Butte creek to the Maclaren River.

Location 18: Chalcopyrite and bornite occur for several hundred zeet along a steep north valley wall in widely separated unoriented fractures in basaltic greenstone. Minor dissemination of sulfide occurs in the volcanics close to some of the fractures, but the combination of fracture mineralization and dissemination is not sufficient to be of economic significance at any place along the zone.

Location 19: Minor amounts of mineralized fragments in the talus containing bornite, chalcopyrite, and chalcocite associated with quartz and epidote occur near the base of the south valley wall. The rock type in the area is greenstone cut by hornblende diorite. The 
mineralized fragments probably represent small pods of quartz and epidote with copper minerals in the volcanics.

Locations 20\&21: Metal occurxences in the mountains south of Butte Creek. Talus in the drainages examined on the south side of the mountains (location 20) revealed minor amounts of malachite and azurite associated with quartz and epidote in the volcanics. These probably represent small sparsely mineralized deposits similar to the ones between the Susitna and Maclaren Rivers.

A deposit of magnetite (location 21) is revealed by rusty colored iron staining and associated black color at an elevation of 4,300 feet along the north wall of a drainage. The occurrence lies along the faulted contact between interbedded argiliite and limestone to the west and a zone of amphibolite cut by basic dike rocks to the east. The amphibolite might represent a zone of concact metamorphism. Structuraliy, the showing occurs on the steep southeasterly dipping limb of a complexly faulted northeasterly striking anticline. The anticline plunges to the southwest. The magnetite zone, which appears to have a northeasterly strike, is only seen in talus, so its extent and geological occurrence is not certain. It could represent a re- placed sedimenicary bed or possibly a segregation associated with the amphibolite. A rusty colored zone of carbonate veining (N $20^{\circ} \mathrm{E}$, vertical) with finely disseminated light green secondary copper minerals cuts the amphibolite. I c assayed less than 0.1 per cent $\mathrm{Cu}$. This carbonate zone, which may represent a fault, can be traced for over 100 feet before it is covered by vegetation to the northwest and talus to the southeast.

A more extensive northeasterly striking rusty iron-stained zone was spotted by ground and airborne reconnaissaince high up on the north side of a northwest trending arainage approximately one-half mile to the northeast of the magnetite occurrence. It appears to follow a northeasterly striking southeasterly dipping sedimentary bed, possibly a limestone. Acidic intrusive rocks occur a short distance to the west. This stained zone was not examined on the grouno.

\section{GEOCHEMICAL SURVEY}

A drainage geochemical survey was conducted throughout the map area by field assistant John Patterson of the University of Alaska. Stream sediments were tested in the field and in the laboratory by the University of Alaska method (Mukherjee and Mark Anthony, 1957). It should be noted, however, that most of the anomalies shown were decected at $\mathrm{pH} 2$; only anomalies 47,60 , and 62 were detected in the pH range 
of 5 to 6 . The stronger anomalies and their probable cause, where evident, are listed belor.

134) A $25 \times$ background reading was recorded at pH2.

135) A $+25 x$ background reading was recorded at pH2. Both of these streams drain copper showing $\neq 8$.

70) A $+25 x$ background reading was recorded at pH2. This stream drains mineralized area 12 , and the anomaly is probably due to anomalous copper associated with the staining in the area.

102) A +2lx background reading was recorded at pH2. The cause of the anomaly is not known.

60) A $20 x$ background reading was recorded at pH5. This sample was taken at mineralized location \#13.

47) A $20 x$ background reading was recorded at pH5. The stream drains an area of argillite cut by numerous quartz and carbonate veinlets (mineralized area 14), but ro definice cause is known for the anomaly.

32) A $+25 x$ background reading was recorded at pH2. This stream drains to the $\mathrm{KM}$ copper prospect (mineralized area 17 ).

78) A $12 \times$ background reading was recorded at pH2. This stream drains mineralized area 10, and the anomaly is probably caused by copper.

\section{SUGGESTIONS FOR PROSPECTING}

The numerous copper occurrences in the volcanic belt point to the possibility of an original anomalously high trace element content associated with this rock type. It is possible to explain the formation of the numerous showings, which in most cases display a lack of strong structural control, by reconcentration of this original anomalous copper content during regional metarorphism. There are undoubtedly numerous undiscovered copper showings in the greenscones, but it is doubtful if they will exceed the size and tenor of the known ones unless controlled by a strong structure. The beds of limestone, which lie along the contact zone between the volcanic and sedimentary belts offer a favorable stratigraphic control for mineralization. The contact zone between the limestones and the volcanics is an attractive exploration possibility for massive replacement type deposits of copper derived from the volcanics, although no deposit of this type is known to occur in the region. Most of the iimestone-volcanic contact zone is either under overburden or in high inaccessible areas.

A systematic visual helicopter reconnaissance traverse across 
the contact zone between the argillite and volcanic belts would be a practical method of prospecting for possible undiscovered outcropping massive sulfide replacement type mineralization in the limestones. special attention should be given to areas where intrusives cut the sediments and volcanics. The mountains south of Butte Creek, the area between Windy Creek and South Pass Creek, the area northeast of the junction between coal and clearwater creeks, and the area north-northwest of the Maclaren prospect all contain acidic stocks in proximity to limy sediments.

Following is a list of specific mineralized-altered areas and geochemical anomalies that appear to warrant further exploration:

1. The rusty colored stained zone at locality 21 in the mountains south of Butte Creek should be examined and sampled. The magnetite zone approximately one-half mile to the south could probably be traced out by a ground magnetometer survey using a reconnaissance type instrument.

2. There is some possibility for copper occurrences in the limestones to the northwest of the mineralized shear on the Greathouseclaims (locality 3). The area where the projections of the limestone bed and the shears intersect is covered by overburden. A soil geochemical study would be an inexpensive way to prospect this overburdencovered area.

3. Locality 8 in the South Pass Creek area should be trenched. The limestone in the area should be carefully prospected for the possibility of further mineralization.

4. The numerous and extensive rusty-colored stained areas to the northeast of Coal and Clearwater Creeks and along the west side of the West Fork of the Maclaren should be examined and sampled in detail. The colored zones visited in the clearwater area all appear to be caused by ankerite and pyrite, but many of them were inaccessible by foot. The stained zone at locality 12 should be closely examined to further study and delineate the molybdenite and chalcopyrite found in the talus. A helicopter would be extremely useful in this work.

5. The source of the magnetite and copper bearing float in the arainage at locality 11 should be prospected for. 
6. Further prospecting is warranted around locality 13. A soil geochemical survey would be an inexpensive method to explore the overburden-covered areas to the north and south.

7. It is possibie that the KM vein mineraliztion is of sufficient strength to show up as an electrical conductor in a ground electromagnetic survey. If this can be ascertained by a test survey, ground EM would be a relatively inexpensive and effective method to prospect the covered areas around the KM prospect for continuation of the known vein or for possible additional covered mineralized zones.

8. Geochemical anomalies 47 and 102 along the West Fork of the Maclaren River and anomaly 70, which occurs on one of the south trending streams draining area 12, should be investigated further. 


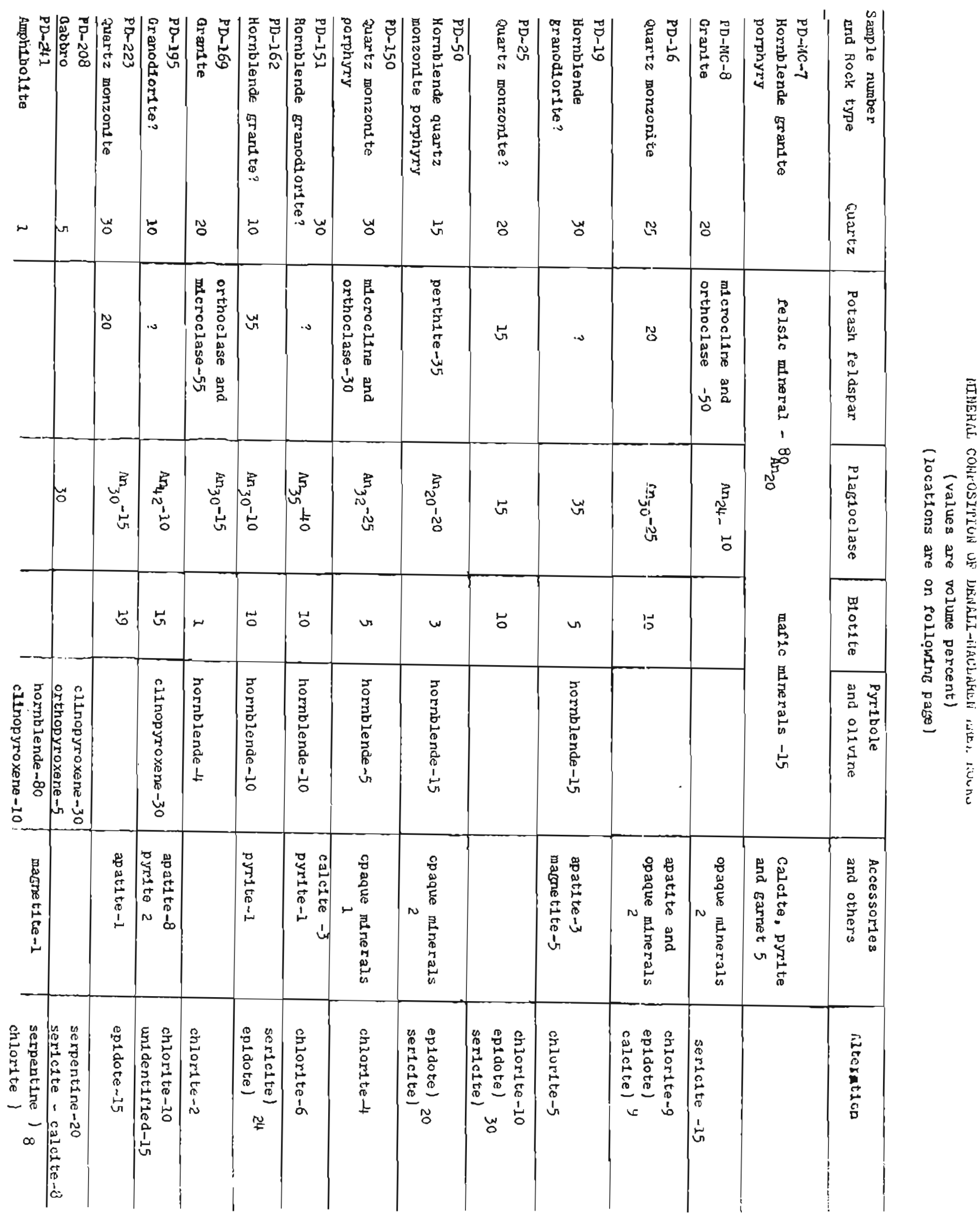


Locations:

PD-iiC-7, 2!' miles NW of Ki: prospect (location 17).

PD-MC-8, 2 3/4 miles its of kil prospect (location 17).

PD-16, 2 miles west of Raft Creek, I mile norch of Denali Highway (mile 70).

PD-19, On Rart Creek, I mile north of Denali Highway (mile 68).

PD-25, Near head of wesit tributary of Raft creek.

PD-50, North side of iindy Creek, due south of Eldorado Creek.

PD-150, East side of Vest fork of laclaren River 1 mile northwest of location 11 .

PD-151, East side of West Fork of ilaclaren River near location 11.

PD-162, Near head of Eldorado Creek.

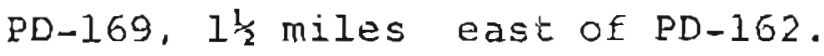

PD-195. North shore of Roosevclt Lake.

PD-223, North side of Timberline Creek.

PD-208, Dike rock at location 8.

PD-24l, South of Butte Creek neal location 21. 


\section{REFERENCES}

Chapman, R.M. and R.H. Saunders.

1954 The Kathleen-Margaret ( $K \mathbb{N}_{1}$ ) Copper Prospect on the Upper Maclaren River, Alaska; U.S. Geological Survey Circ. 332 $5 \mathrm{p}$.

Moffit, E.H.

1912 Headwater Region of Gulkana and Susitna Rivers, Alaska; U.S. Geological survey Bull. 498, 82 p.

Mukherjee, N.R. and L. Hark Anthony.

1957 Geochemical Prospecting; University of Alaska, School of Vines Bulletin 3, 81 p.

Ross, C.P.

1933 The Valdez Creek irining District, Alaska; U.S. Geological Survey Bull. 349-H, p. 425-453.

Saunders, R.H.

1961 Susitna-Maclaren Area; State of Alaska, Division of iines and Minerals, Report for the Year 1961, p. 37-40. 